\title{
MTAP Negative
}

National Cancer Institute

\section{Source}

National Cancer Institute. MTAP Negative. NCI Thesaurus. Code C156051.

An indication that MTAP expression or activity has not been detected in a sample. 